\title{
Correction: Implications of hematopoietic stem cells heterogeneity for gene therapies
}

\author{
Jeremy Epah • Richard Schäfer (1)
}

Published online: 4 March 2021

(c) The Author(s) 2021. This article is published with open access

Correction to: Gene Ther

https://doi.org/10.1038/s41434-021-00229-x

On page 3 we mention a cell dose; it should read " $2 \times 10^{6}$ CD34+ cells" and not " $2 \times 106$ CD34+ cells".

This has now been corrected in both the PDF and HTML versions of this article.
Open Access This article is licensed under a Creative Commons Attribution 4.0 International License, which permits use, sharing, adaptation, distribution and reproduction in any medium or format, as long as you give appropriate credit to the original author(s) and the source, provide a link to the Creative Commons license, and indicate if changes were made. The images or other third party material in this article are included in the article's Creative Commons license, unless indicated otherwise in a credit line to the material. If material is not included in the article's Creative Commons license and your intended use is not permitted by statutory regulation or exceeds the permitted use, you will need to obtain permission directly from the copyright holder. To view a copy of this license, visit http://creativecommons. org/licenses/by/4.0/. 